\title{
Relationship of the erythrocyte sedimentation rate to acute phase proteins in polymyalgia rheumatica and giant cell arteritis
}

\author{
J. R. PARK, J. G. JONES, AND B. L. HAZLEMAN
}

From Addenbrooke's Hospital, Cambridge

SUMMARY We have compared the erythrocyte sedimentation rate (ESR) with other acute phase proteins (C-reactive protein (CRP), $\alpha_{1}$ antitrypsin, orosomucoid, and haptoglobin) in 108 patients with polymyalgia rheumatica and/or giant cell arteritis. There was good correlation between CRP and ESR, but the ESR was also found to have the highest correlation with disease activity. The additional measurement of CRP or other acute phase proteins may be of value in a minority of cases.

Polymyalgia rheumatica (PMR) and giant cell arteritis (GCA) are related diseases which can present in a nonspecific manner, although the muscle pain, constitutional disturbance, and headaches may be attributed to depression.

In the majority of patients an elevated erythrocyte sedimentation rate (ESR) aids in the diagnosis of PMR or GCA. However, normal ESRs have been reported $^{1-3}$ together with subsequent elevation. ${ }^{34}$ The ESR rapidly returns to normal with corticosteroid therapy and is used as a guide for the adjustment of treatment. However, clinical relapse may occur while the ESR is normal. More frequently, the ESR falls from its initial level and remains above normal for the patient's age. ${ }^{56}$

The ESR is a measure of abnormal concentrations of fibrinogen, serum globulins, and other acute phase proteins. Elevated levels of individual acute phase proteins $^{7-9}$ have been found in PMR/GCA and in rheumatoid arthritis (RA). In a group of RA patients measurement of both C-reactive protein (CRP) and ESR was more helpful than either alone in assessing disease activity. ${ }^{10}$

We present the results of measuring ESR, CRP, $\alpha_{1}$ antitrypsin, orosomucoid, and haptoglobin in a group of 108 patients with PMR or GCA. The results were included in a correlation analysis together with an assessment of disease activity to determine whether the ESR is the investigation of choice.

\section{Patients and methods}

One hundred and eight patients presenting at Addenbrooke's Hospital, Cambridge, with GCA or Accepted for publication 15 December 1980

Correspondence to $\mathrm{Dr} \mathrm{B}$. L. Hazleman, Addenbrooke's Hospital, Hills Road, Cambridge CB2 2QQ.
PMR between January 1974 and March 1979 were assessed clinically and by measurement of the ESR and acute phase proteins. Forty-seven patients were seen in the acute stage of their disease, and their progress with treatment was followed. Forty patients were assessed once and 21 at least twice while receiving treatment.

The criteria for diagnosis were as follows:

$P M R$. (1) Shoulder and pelvic girdle pain which was primarily muscular in the absence of true muscle weakness; (2) morning stiffness; (3) duration of at least 2 months unless treated; (4) ESR over $30 \mathrm{~mm} / \mathrm{h}$ or CRP over $6 \mu \mathrm{g} / \mathrm{ml}(6 \mathrm{mg} / \mathrm{l})$. (5) absence of evidence of rheumatoid or other inflammatory arthritis or malignant disease; (6) absence of objective signs of muscle disease; (7) prompt and dramatic response to systemic corticosteroids when used.

$G C A$. (1) A positive temporal artery biopsy, or (2) (i) cranial artery tenderness noted by a physician; (ii) one or more of the following features: $(a)$ visual disturbance, $(b)$ headache, $(c)$ jaw pain, $(c)$ cerebrovascular insufficiency; (3) ESR over $30 \mathrm{~mm} / \mathrm{h}$ or CRP over $6 \mu \mathrm{g} / \mathrm{ml}(6 \mathrm{mg} / \mathrm{l})$; (4) prompt and dramatic response to systemic corticosteroids when used.

$P M R / G C A$ indicates a patient showing symptoms of both diseases.

Grading of disease activity. At the time of taking the blood sample the clinical activity of both the PMR and GCA components of the disease were assessed on a scale from 0 to 4 (inactive to highly active). For example, a patient with severe myalgia and a slightly tender temporal artery would be graded P4:G1.

The clinical diagnosis and results of temporal artery biopsy are shown in Table 1. 
Table 1 Clinical diagnosis and results of temporal artery biopsy

\begin{tabular}{lcccc}
\hline Diagnosis & $\begin{array}{l}\text { No. of } \\
\text { patients }\end{array}$ & \multicolumn{3}{l}{ Temporal artery biopsy } \\
\cline { 4 - 5 } & & Positive & Negative & Not performed \\
\hline PMR alone & 34 & 0 & 11 & 23 \\
PMR/GCA & 51 & 22 & 20 & 9 \\
GCA alone & 23 & 17 & 5 & 1 \\
Total & 108 & 39 & 36 & 33 \\
\hline
\end{tabular}

Methods. The ESR was measured in the routine haematology laboratory by the Westergren method, readings taken at 1 hour. We accepted $20 \mathrm{~mm} / \mathrm{h}$ as the upper limit of normal. CRP was measured by Mancini single radial immunodiffusion (Behringwerke anti-CRP serum) with a commercial standard CRP serum (Behringwerke) (normal range mean $\pm 2 \mathrm{SD}, 0-6 \mu \mathrm{g} / \mathrm{ml}(0-6 \mathrm{mg} / \mathrm{l}))$. $\alpha_{1}$ Antitrypsin, orosomucoid, and haptoglobin were measured in the routine clinical biochemistry laboratory by agarose gel electrophoresis. ${ }^{11}$ (normal ranges mean $\pm 2 \mathrm{SD}$, $\alpha_{1}$ antitrypsin $80-140 \%$ normal, orosomucoid $80-140 \%$ normal, haptoglobin $50-160 \%$ normal).

\section{Results}

Spearman rank correlation coefficients between the various acute phase protein measurements and disease activity grades are shown in Table 2 . The acute phase proteins were all positively related, with the highest correlations occurring between CRP and orosomucoid $(r=0.72)$ and CRP and ESR $(r=$ $0 \cdot 66$ ). The correlation analysis further indicates that the ESR is the best indicator of disease activity.

Looking specifically at the ESR and CRP, we found the results were either both above or both below the upper limit of normal in 200 instances. There was a discrepancy in 49 paired results (representing 35 patients) where the CRP was raised in the presence of a normal ESR or vice versa, but this disagreement occurred only during less active disease (Table 3).

Table 4 shows the acute phase protein results in
Table 3 Disease activity (either $P$ or $G$ ) at time of sample

\begin{tabular}{|c|c|c|c|c|c|c|}
\hline & 0 & 1 & 2 & 3 & 4 & Total \\
\hline $\left.\begin{array}{l}\mathrm{ESR}>20 \mathrm{~mm} / \mathrm{h} \\
\mathrm{CRP} \leqslant 6 \mu \mathrm{g} / \mathrm{ml}\end{array}\right\}$ & 16 & 4 & 4 & 0 & 0 & 24 \\
\hline $\left.\begin{array}{l}\mathrm{ESR} \leqslant 20 \mathrm{~mm} / \mathrm{h} \\
\mathrm{CRP}>6 \mu \mathrm{g} / \mathrm{ml} 6\end{array}\right\}$ & 17 & 3 & 5 & 0 & 0 & 25 \\
\hline
\end{tabular}

the GCA, PMR, and PMR/GCA categories according to disease activity $(0,1+2,3+4)$. ESR and CRP are both initially high and quickly return to within the normal range. $\alpha_{1}$ antitrypsin is also elevated during active disease and falls to within the normal range as disease activity falls; only 2 patients had a level below the normal range. Orosomucoid and haptoglobin were more strikingly elevated during active disease but tended to remain above the upper limit of normal when the disease became less active. There is a tendency for the acute phase protein results to be highest during active disease (grades 3 or 4) in the patients with GCA alone.

It is noteworthy that the ESR returned to below $20 \mathrm{~mm} / \mathrm{h}$ at some stage during treatment in all but 2 cases. One of these patients was found to haveo long-standing benign monoclonal gammopathys which would account for his persistently raised ESR In the other patient the ESR remained between 25 and $35 \mathrm{~mm} / \mathrm{h}$.

\section{Discussion}

This study has shown positive correlations between ESR, CRP, $\alpha_{1}$ antitrypsin, orosomucoid, and haptoglobin in treated and untreated patients with PMR and/or GCA. While there was some discrepancy between ESR and CRP in patients with inactive (grade 0 ) or slightly active disease (grade 1 or 2), the measurements were invariably in agreement in patients with active disease (grade 3 or 4 ). There was nothing to suggest from this study that any other measurement was superior to the ESR, which showed the highest correlations with disease activity. In those occasional cases where the ESR is normal in the

Table 2 Spearman rank correlation matrix: acute phase protein levels and disease activity grades

\begin{tabular}{|c|c|c|c|c|c|c|}
\hline$E S R$ & $C R P$ & $\alpha_{1}$ Antitrypsin & Orosomucoid & Haptoglobin & $\begin{array}{l}\text { Symptoms of } \\
P M R(P)\end{array}$ & $\begin{array}{l}\text { Symptoms of } \\
G C A(G)\end{array}$ \\
\hline $\begin{array}{l}\text { ESR } n=292 \\
\text { CRP } n=273 \\
\alpha_{1} \text { Antitrypsin } n=154 \\
\text { Orosomucoid } n=152 \\
\text { Haptoglobin } n=152\end{array}$ & $0.66^{* * *}$ & $\begin{array}{l}0 \cdot 49^{* * * *} \\
0 \cdot 32^{* * *}\end{array}$ & $\begin{array}{l}0 \cdot 61^{* * *} \\
0 \cdot 72^{* * *} \\
0 \cdot 57^{* * *}\end{array}$ & $\begin{array}{l}0 \cdot 43^{* * * *} \\
0 \cdot 55^{* * *} \\
0 \cdot 38^{* * *} \\
0 \cdot 65^{* * *}\end{array}$ & $\begin{array}{l}0 \cdot 56^{* * *} \\
0 \cdot 34^{* * *} \\
0 \cdot 35^{* * *} \\
0 \cdot 45^{* * *} \\
0 \cdot 39^{* * *}\end{array}$ & $\begin{array}{l}0 \cdot 45^{* * *} \\
0 \cdot 38^{* * * *} \\
0 \cdot 44^{* * *} \\
0 \cdot 38^{* * *} \\
0 \cdot 20^{*}\end{array}$ \\
\hline
\end{tabular}

${ }^{*} \mathrm{p}<0.05 .{ }^{* * *} \mathrm{p}<0.001$. 
Table 4 Acute phase protein results according to diagnosis and disease activity grades

\begin{tabular}{|c|c|c|c|c|c|c|c|c|c|c|c|c|c|c|c|c|}
\hline & & \multicolumn{3}{|c|}{$\begin{array}{l}\text { ESR }(\mathrm{mm} / \mathrm{h}) \\
\text { Disease activity }\end{array}$} & \multicolumn{3}{|c|}{$\begin{array}{l}C R P(\mu \mathrm{g} / \mathrm{ml}) \\
\text { Disease activity }\end{array}$} & \multicolumn{3}{|c|}{$\begin{array}{l}\alpha_{1} \text { Antitrypsin } \\
(\% \text { normal }) \\
\text { Disease activity }\end{array}$} & \multicolumn{3}{|c|}{$\begin{array}{l}\text { Orosomucoid } \\
\text { (\% normal) } \\
\text { Disease activity }\end{array}$} & \multicolumn{3}{|c|}{$\begin{array}{l}\text { Haptoglobin } \\
\text { ( } \% \text { normal) } \\
\text { Disease activity }\end{array}$} \\
\hline & & 0 & $1+2$ & $3+4$ & 0 & $1+2$ & $3+4$ & 0 & $1+2$ & $3+4$ & 0 & $1+2$ & $3+4$ & 0 & $1+2$ & $3+4$ \\
\hline$P M R$ & $\begin{array}{l}\text { Mean } \\
\text { SD } \\
n\end{array}$ & $\begin{array}{l}18 \cdot 3 \\
14 \cdot 8 \\
54\end{array}$ & $\begin{array}{l}23 \cdot 5 \\
13 \cdot 5 \\
26\end{array}$ & $\begin{array}{l}57 \cdot 9 \\
14 \cdot 7 \\
20\end{array}$ & $\begin{array}{r}4 \cdot 5 \\
5 \cdot 8 \\
54\end{array}$ & $\begin{array}{r}8 \cdot 5 \\
9 \cdot 2 \\
24\end{array}$ & $\begin{array}{l}61 \cdot 3 \\
54 \cdot 6 \\
13\end{array}$ & $\begin{array}{r}115 \\
23 \\
32\end{array}$ & $\begin{array}{r}145 \\
15 \\
9\end{array}$ & $\begin{array}{r}168 \\
71 \\
12\end{array}$ & $\begin{array}{r}146 \\
45 \\
32\end{array}$ & $\begin{array}{r}187 \\
56 \\
9\end{array}$ & $\begin{array}{r}282 \\
73 \\
12\end{array}$ & $\begin{array}{r}170 \\
61 \\
32\end{array}$ & $\begin{array}{r}169 \\
81 \\
9\end{array}$ & $\begin{array}{r}333 \\
76 \\
12\end{array}$ \\
\hline$P M R / G C A$ & $\begin{array}{l}\text { Mean } \\
\text { SD } \\
\mathbf{n}\end{array}$ & $\begin{array}{l}14 \cdot 8 \\
10 \cdot 4 \\
52\end{array}$ & $\begin{array}{l}21 \cdot 3 \\
17 \cdot 3 \\
54\end{array}$ & $\begin{array}{l}59 \cdot 5 \\
27 \cdot 5 \\
20\end{array}$ & $\begin{array}{r}4 \cdot 6 \\
7 \cdot 6 \\
51\end{array}$ & $\begin{array}{l}7 \cdot 6 \\
12 \cdot 1 \\
54\end{array}$ & $\begin{array}{l}44 \cdot 4 \\
69 \cdot 6 \\
16\end{array}$ & $\begin{array}{r}120 \\
22 \\
27\end{array}$ & $\begin{array}{r}123 \\
17 \\
28\end{array}$ & $\begin{array}{c}190 \\
81 \\
13\end{array}$ & $\begin{array}{r}165 \\
46 \\
26\end{array}$ & $\begin{array}{r}159 \\
39 \\
28\end{array}$ & $\begin{array}{r}270 \\
87 \\
13\end{array}$ & $\begin{array}{r}168 \\
51 \\
25\end{array}$ & $\begin{array}{r}196 \\
65 \\
28\end{array}$ & $\begin{array}{r}279 \\
120 \\
13\end{array}$ \\
\hline$G C A$ & $\begin{array}{l}\text { Mean } \\
\text { SD } \\
\mathbf{n}\end{array}$ & $\begin{array}{l}12 \cdot 8 \\
10 \cdot 7 \\
34\end{array}$ & $\begin{array}{l}35 \cdot 4 \\
25 \cdot 6 \\
18\end{array}$ & $\begin{array}{l}91 \cdot 0 \\
33 \cdot 3 \\
14\end{array}$ & $\begin{array}{l}8 \cdot 7 \\
8 \cdot 1 \\
32\end{array}$ & $\begin{array}{l}11 \cdot 1 \\
11 \cdot 9 \\
19\end{array}$ & $\begin{array}{c}101 \cdot 1 \\
55 \cdot 4 \\
10\end{array}$ & $\begin{array}{r}123 \\
26 \\
19\end{array}$ & $\begin{array}{r}132 \\
15 \\
6\end{array}$ & $\begin{array}{r}226 \\
40 \\
8\end{array}$ & $\begin{array}{r}166 \\
41 \\
19\end{array}$ & $\begin{array}{r}173 \\
50 \\
6\end{array}$ & $\begin{array}{r}320 \\
68 \\
8\end{array}$ & $\begin{array}{r}209 \\
75 \\
19\end{array}$ & $\begin{array}{r}157 \\
86 \\
6\end{array}$ & $\begin{array}{r}313 \\
132 \\
8\end{array}$ \\
\hline
\end{tabular}

Figures in italics $=$ mean above normal range.

presence of active disease, measurement of other acute phase proteins may be worthwhile. Only 1 of our patients with PMR had a normal ESR on presentation, a modestly elevated CRP being present in this case. The ESR is the simplest investigation to perform and therefore at the moment remains the investigation of choice.

\section{References}

1 Cullen J F. Occult temporal arteritis. Trans Opthalmol Soc UK 1963; 83: 725-36.

2 Mowat A G, Hazleman B L. Polymyalgia rheumatica. A clinical study with particular reference to arterial disease. $J$ Rheumatol 1974; 1: 190-202.

3 Healey L A, Wilske K R. Manifestations of giant cell arteritis. Med Clin North Am 1977; 61: 261-70.

4 Hunder G G, Sheps S G. Intermittent claudication and polymyalgia rheumatica. Arch Intern Med 1967; 119: 638-43.

5 Boyd R V, Hoffbrand B I. Erythrocyte sedimentation rate in elderly hospital in-patients. Br Med J 1966; i: 901-2.

${ }^{6}$ Hayes G S, Stinson I N. Erythrocyte sedimentation rate and age. Arch Ophthalmol 1976; 94: 939-40.

7 Malmvall B E, Bengtsson B A. Giant cell arteritis. Clinical features and involvement of different organs. Scand J Rheumatol 1978; 7: 154-8.

8 Wadman B, Werner I, Observations on temporal arteritis. Acta Med Scand 1972; 192: 377-83.

9 Wilske K R, Healey L A. Polymyalgia rheumatica. A manifestation of systemic giant cell arteritis. Ann Intern Med 1967; 66: 77-85.

10 Amos R S, Constable T J, Crockson R A, et al. Rheumatoid arthritis-relation of serum $C$-reactive protein and erythrocyte sedimentation rates to radiographic changes. Br Med J 1977; i: 195-7.

11 Jeppsson J O, Laurell C B, Franzen B. Agarose gel electrophoresis. Clin Chem 1979; 25 : 629-38. 